Kodifikasia : Jurnal Penelitian Islam, Vol 15, No. 01 (2021), 171-184

DOI : 10.21154/kodifikasia.v15i1.2689

ISSN : 1907-6371 (Cetak)

ISSN : 2527-9254 (Online)

\title{
VIRUS CORONA DAN DAMPAKNYA TERHADAP PARIWISATA HALAL DUNIA
}

\author{
Shinta Maharani*, Asmak Ab Rahman**
}

\begin{abstract}
ABSTRAK:
Wabah Covid-19menyebabkan dampak kerugian pada berbagai sektor ekonomi termasuk pariwisata halal. Larangan dari berbagai belahan dunia untuk keluar masuk telah menekan sumber pendapatan utama sektor pariwisata. Status waspada virus corona yang dinaikkan dari kuning menjadi merah, yang menandakan penyebaran virus corona sangat serius dan berdampak luas bagi kesehatan masyarakat.Kerugian secara ekonomi ini terjadi karena banyaknya wisatawan dari berbagai negara di dunia yang membatalkan liburan mereka karena takut tertular Covid-19. Hal baru dari paper ini adalah kurangnya penelitian yang mencoba menghubungkan antara dampak virus corona terhadap pariwisata halal. Adapun tujuan dari paper ini adalah: 1. Mendeskripsikan hubungan kausalitas antara virus corona dan dampaknya terhadap pariwisata halal. 2. Meningkatkan efisiensi di sektor pariwisata halal melalui destinasi domestik. 3. Menganalisis dampak virus corona yang menekan pariwisata halal. Metode penelitian ini menggunakan metode kualitatif dan data instrumen yang digunakan adalah data sekunder berupa dokumentasi. Temuan paper ini menunjukkan bahwa virus corona secara signifikan memengaruhi masa depan pariwisata halal di destinasi global, sehingga destinasi domestik adalah solusi dari dampak virus corona untuk mencegah kerugian yang lebih besar pada pariwisata halal. Virus coronavirus menyatukan aktor-aktor utama yang terkait dengan pariwisata halal: medis, kebijakan global dan domestik, akademisi, fasilitas, layanan elektronik, akomodasi dan penerbangan.
\end{abstract}

Kata Kunci : Virus Corona; Pariwisata Halal; Destinasi Global

* Institut Agama Islam Negeri Ponorogo, Indonesia, email: maharani@ iainponorogo.ac.id

** Akademi Studi Islam, Universitas Malaya Malaysia, email: maharani@ iainponorogo.ac.id 


\begin{abstract}
:
The Covid-19 outbreak has a detrimental impact on various economic sectors, including halal tourism. The prohibition from various parts of the world to go in and out has suppressed the main source of income for the tourism sector. The coronavirus alert status has been raised from yellow to red, which indicates the spread of the coronavirus is very serious and has a wide impact on public health. This economic loss occurred because many tourists from various countries in the world canceled their holidays for fear of contracting Covid-19. The novelty of this paper is the lack of research that tries to link the impact of the coronavirus on halal tourism. The objectives of this paper are 1. To describe the causal relationship between the coronavirus and its impact on halal tourism. 2. Increase efficiency in the halal tourism sector through domestic destinations. 3. Analyzing the impact of the coronavirus that suppresses halal tourism. This paper method uses qualitative methods and data used is secondary data in the form of documentation. The findings of this paper indicate that the coronavirus significantly affects the future of halal tourism in global destinations and domestic destinations is a solution to prevent greater losses in halal tourism. The coronavirus brings together the main actors related to halal tourism: medical, global and domestic policy, academia, facilities, electronic services, accommodation, and aviation.
\end{abstract}

Keywords : Coronavirus; Halal Tourism; Global Destination

\title{
PENDAHULUAN
}

Wabah virus Corona (Covid-19) telah menyebabkan dampak kerugian pada berbagai sektor ekonomi termasuk sektor pariwisata halal, larangan dari berbagai belahan dunia untuk keluar dan masuk telah menekan sumber pendapatan utama di sektor pariwisata. Status waspada virus corona yang dinaikkan statusnya dari kuning menjadi merah, mengindikasikan penyebaran virus corona sangat serius dan berdampak luas bagi kesehatan masyarakat. Banyak turis yang menunda liburannya keluar negeri di tengah merebaknya virus ini. Kerugian secara ekonomi ini terjadi karena banyaknya wisatawan dari berbagai negara di dunia yang membatalkan liburan perjalanan mereka karena takut tertular Covid-19.Kerugian terjadi karena banyak wisatawan di seluruh dunia membatalkan perjalanan liburan/ ataupun secara spesifik perjalanan tersebut untuk tujuan keagamaannya akibat larangan perjalanan covid-19. Belakangan ini, covid-19 telah 
menunjukkan kekuatan pandemiknya ${ }^{1}$ Peristiwa merugikan ini termasuk skenario ekonomi yang tidak biasa ${ }^{2} \mathrm{Di}$ saat banyak negara di dunia terpaksa menjalani masa karantina ${ }^{3}$ penyebaran global infeksi virus corona terus meningkat.

Tabel 1. Jumlah Kasus Covid-19 di Dunia

\begin{tabular}{|c|c|c|c|c|}
\hline Tidak. & Negara & Kasus & Meninggal & Sembuh \\
\hline 1. & Amerika & 610.632 & 25.856 & 38.562 \\
\hline 2. & Serikat & 172.541 & 18.056 & 67.504 \\
\hline 3. & Spanyol & 162.488 & 21.067 & 37.130 \\
\hline 4. & Italia & 143.303 & 15.729 & 28.805 \\
\hline 5. & Perancis & 131.359 & 3.294 & 68.200 \\
\hline 6. & Jerman & 93.873 & 12.107 & 344 \\
\hline 7. & Inggris & 82.249 & 3.341 & 77.738 \\
\hline 8. & Cina & 74.877 & 4.683 & 48.129 \\
\hline 9. & Iran & 65.111 & 1.403 & 4.799 \\
\hline 10. & Turki & $\frac{31.119}{1567552}$ & $\frac{4.157}{109693}$ & $\frac{6.868}{378070}$ \\
\hline
\end{tabular}
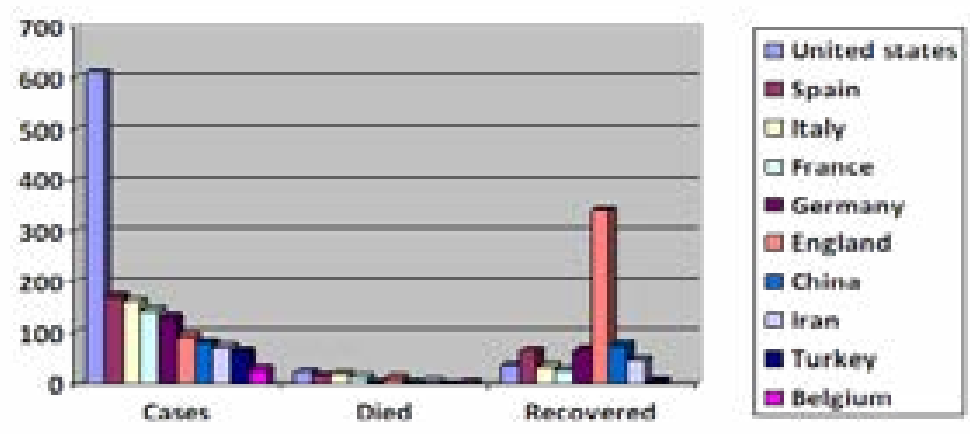

Gambar 1. Jumlah Kasus Covid-19 di Dunia Tahun 2020

Berdasarkan angka dari worldometers di atas, jumlah kasus virus corona atau covid19 telah mencapai 1.567 .552 kasus pada tanggal 15 April 2020, dari jumlah tersebut sebanyak 467.074 pasien dinyatakan sembuh

${ }^{1}$ Koonin, L. M. (2020). Novel coronavirus disease (COVID-19) outbreak: Now is the time to refresh pandemic plans. Journal of Business Continuity $\mathcal{E}$ Emergency Planning, 13(4), 1-15.

2 The Global Macroeconomic Impacts of COVID-19: Seven Scenarios by Warwick J. McKibbin, Roshen Fernando: SSRN. (n.d.). Retrieved June 14, 2021, from https://papers. ssrn.com/sol3/papers.cfm?abstract_id $=3547729$

${ }^{3}$ Anderson, R. M., Heesterbeek, H., Klinkenberg, D., \& Hollingsworth, T. D. (2020). How will country-based mitigation measures influence the course of the COVID-19 epidemic? Lancet (London, England), 395(10228), 931-934. https://doi.org/10.1016/ S0140-6736(20)30567-5 


\section{4 | Shinta Maharani, Asmak Ab Rahman}

Worldometer, 2020. Pandemi mulai dapat berkurang ketika masyarakat memahami cara penanganannya, dan vaksin telah dikembangkan dan didistribusikan secara luas. ${ }^{4}$ Peneliti melihat riwayat pandemi masa lalu untuk membuat prediksi awal tentang kapan pandemi virus corona akan berakhir. Pada umumnya, pandemi biasanya berlangsung antara 12 hingga 36 bulan, oleh karena itu masalah kebijakan penerbangan dan pariwisata antar negara menjadi terbatas dan ketat; Inilah salah satu alasan peneliti mencoba meneliti pariwisata halal yang terdampak dari virus corona.

Tujuan dari pembahasan artikel ini dalam rangka mendeskripsikan hubungan kausalitas antara dampak virus corona terhadap pariwisata halal, meningkatkan efisiensi di bidang halal pariwisata melalui destinasi domestik dan menganalisis bagaimana dampak virus corona yang menekan pariwisata halal.

\section{PEMBAHASAN}

\section{Kerangka Konseptual dan Identifikasai Masalah}

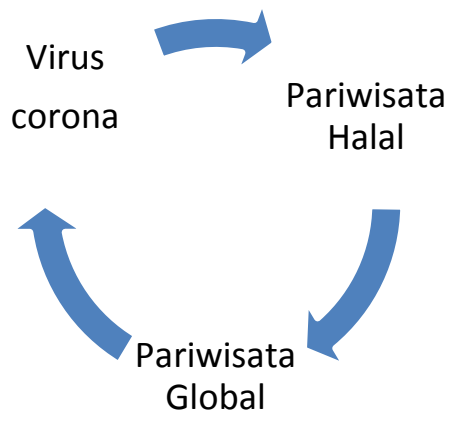

Gambar 2. Kerangka Konseptual

Sebagaimana digambarkan dari kerangka koseptual di atas, virus corona 2019 dinilai sebagai bencana dan berdampak pada pariwisata halal secara global. Hal itu akan berdampak pada resesi ekonomi karena banyak sektor yang terkena imbasnya. Apapun kondisinya, virus corona segera membutuhkan solusi karena terkait dengan kesehatan dan keselamatan serta resesi ekonomi secara global.

Masalah konsekuensi logis pada kebijakan antar negara yang berbeda; masalah visa dan peraturan penerbangan tentang larangan

${ }^{4}$ Dr. Faheem Younus: During coronavirus pandemic, leave denial, leave panic. Live in preparedness [Commentary]-Baltimore Sun. (n.d.). Retrieved June 14, 2021, from https://www.baltimoresun.com/maryland/harford/aegis/opinion/cng-ag-commentarycoronavirus-younus-20200318-5xymml75ajal3fotzsibvqhfjq-story.html

Kodifikasia: Jurnal Penelitian Islam, Volume, 15 No. 1 Tahun 2021 
bepergian dari pemerintah, pembatasan turis, termasuk hak kesehatan, keselamatan dan untuk menjamin "perdamaian" di negara lain. ${ }^{5}$ Masalah juga bukan hanya terkait dengan masalah kebijakan, aplikatif, praktis, administratif, akan tetapi juga terkait dengan kepedulian sehat, sehingga kebebasan individu/ turisuntuk melintasi dunia menjadi bergeser. ${ }^{6} \mathrm{Hal}$ ini membutuhkan solusi karena semangat dari pariwisata halal adalah mencari dan mendapatkan "kebahagiaan", sedangkan bagi negara turis merupakan sumber "keuangan". ${ }^{7}$ Dari hal tersebut maka terdapat permasalahan yang membutuhkan solusi:

1. Inovasi: Apa saja instrumen inovatif yang berguna untuk memanggulangi dampak Covid-19 terkait dengan pariwisata halal?

2. Aspek pasar: Apa saja strategi pariwisata halal domestik yang akan diadopsi oleh pemerintah? Karena sektor seperti pariwisata yang dihadapi merupakan ancaman yang signifikan yang berjuang untuk mengatasi kerugiannya.

3. Model bisnis: Model bisnis baru apa yang akan dialami untuk sistem pemulihan keuangan terkait pariwisata halal?

4. Sosial: Bagiamana peran pariwisata halal dalam menawarkan berbagai perangkat sosial, yang dapat menjadi tindakan penggerak di tingkat terkait dengan donasi sosial?

\section{Pariwisata Halal}

Secara bahasa, pariwisata halal berasal dari kata halal dan pariwisata. Halal artinya "terlepas" (dari larangan), sedangkan pariwisata berasal dari bahasa Inggris tourism yang artinya pariwisata. ${ }^{8}$ Pengertian pariwisata halal merupakan bagian dari industri pariwisata yang ditujukan untuk wisatawan muslim. Pelayanan pariwisata dalam pariwisata halal mengacu pada aturan Islam. ${ }^{9}$ Dalam definisi yang lain, pariwisata halal merupakan semua objek atau tindakan yang diperbolehkan menurut ajaran Islam untuk digunakan atau ditempati oleh umat Islam dalam industri pariwisata ${ }^{10}$ dari sini hukum

\footnotetext{
${ }^{5}$ Peristiwo, H. (2020). Indonesian and Malaysian potential for a Halal Tourism Industry. Tourism and Leisure, 9, 16.

${ }^{6}$ Kodirov, D., Mavlonova, U., Kodirov, T., \& Allayarova, N. (2020). Halal Tourism in Central Asia: Developing Service Systems in Uzbekistan. 1(2), 11.

7 Fitrianto, F. (2019). Pengembangan Ekonomi Indonesia Berbasis Wisata Halal. BISNIS: Jurnal Bisnis dan Manajemen Islam, 7(1), 69. https://doi.org/10.21043/bisnis. $v 7 i 1.5254$

${ }^{8}$ Azam, S. E., Abdullah, M. A., \& Razak, D. A. (2019). Halal Tourism: Definition, Justification, And Scopes Towards Sustainable Development. 18(3), 9.

${ }_{9}$ Jaelani, A. (2017). Halal Tourism Industry in Indonesia: Potential and Prospects. SSRN Electronic Journal. https://doi.org/10.2139/ssrn.2899864

${ }^{10}$ Battour, M., Hakimian, F., Ismail, M. N., \& Boğan, E. (2018). The Perception of Non-Muslim Tourists towards Halal Tourism: Evidence from Turkey and Malaysia. Journal
} 
Islam (syariah) dipandang sebagai dasar bagipenyediaan produk dan layanan pariwisata bagi konsumen Muslim, seperti hotel, resor, restoran, dan pariwisata halal. Adapun 6 kebutuhan dasar wisatawan muslim dari 130 negara didunia, antara lain: ${ }^{11}$

1. Makanan halal

2. Fasilitas sholat

3. Kamar mandi dengan air untuk wudhu

4. Layanan selama bulan Ramadhan

5. Pencantuman label halal

6. Fasilitas rekreasi

Kesadaran dan pemasaran pariwisata halal, dapat dilihat melaluiindicator: ${ }^{12}$

1. Kemudahan komunikasi

2. Jangkauan dan kesadaran akan kebutuhan wisatawan Muslim

3. Konektivitas transportasi udara

4. Kemudahan persyaratan visa

Stakeholder atau pemerintah seharusnya memiliki komitmen terhadap destinasi pariwisata halal sehingga lokasinya bisa dimasuki oleh seluruh anggota keluarga, bapak-ibu dan anak. ${ }^{13}$ Dari segi keamanan publik juga dijaga dengan baikoleh pihak keamanan (polisi/satpam) dan staf. Yang tidak kalah pentingnya adalah pilihan makanan dan jaminan halal, yaitu komitmen restoran dan penyedia makanan lainnya, serta akses ke tempat ibadah. ${ }^{14}$ Fasilitas di bandara dilengkapi dengan tempat ibadah yang layak, serta pilihan akomodasi seperti transportasi dan hotel yang cocok untuk wisatawan muslim, tentunya ketersediaan alat sholat dan penunjuk arah kiblat di toilet kamar hotel yang menggunakan air. Tak lupa pula pemandu wisatanya yang dapat menjaga komunikasi yang baik dan memakai baju sopan sesuai standar muslim, dan mengingatkan wisatawan untuk sholat tepat waktu. ${ }^{15}$

of Islamic Marketing, 9(4), 823-840. https://doi.org/10.1108/JIMA-07-2017-0072

${ }^{11}$ Global Muslim Travel Index 2018. (n.d.). Retrieved June 14, 2021, from https:// www.crescentrating.com/reports/mastercard-crescentrating-global-muslim-travel-indexgmti-2018.html

${ }^{12}$ Destiana, R., \& Kismartini, K. (2020). Halal Tourism Marketing in the Disruption Era: A Case Study of Penyengat Island in Riau Islands Province. Society, 8(1), 264-283. https://doi.org/10.33019/society.v8i1.174

${ }^{13}$ Djakfar, D. H. M. (n.d.). Peta Jalan Menuju Pengembangan Akademik Eु Industri Halal di Indonesia. 238.

${ }^{14}$ Pesona, S. (n.d.). Pedoman Pariwisata Halal Jawa Barat. 56.

${ }^{15}$ Syahid, P. D. W. H. D.-V. G. 2016. (2015, July 22). Pariwisata Halal: Pengertian, Prinsip dan Prospeknya. Studi Pariwisata. https://studipariwisata.com/referensi/pariwisatahalal/ 
Wisatawan mengunjungi suatu destinasi pariwisata dengan tujuan untuk mencari berbagai pengalaman dan kepuasan psikis dan fisik, hal inilah yang secara umum memotivasi dan menjadi latar belakang seseorang untuk melakukan perjalanan, ${ }^{16}$ Adapun motivasi wisatawan untuk melakukan wisata antara lain:

1. Spiritual dan Religius (Pariwisata Halal);

2. Pleasure (kesenangan), dengan tujuan "kabur" sejenak dari rutinitas sehari-hari;

3. Relaksasi, istirahat dan rekreasi (istirahat untuk menghilangkan stress), menjaga kesehatan tubuh dan pikiran, dengan mengunjungi lingkungan yang berbeda memberikan kesan damai dan sehat;

4. Kesehatan (wisata kesehatan), yaitu mengunjungi tempat-tempat yang dapat membantu memelihara kesehatan atau dalam rangka pengobatan;

5. Partisipasi dalam olah raga (olah raga rekreasi);

6. Curiosity and culture. Motivasi yang melatarbelakangi seseorang untuk berkunjung adalah keinginan untuk melihat destinasi pariwisata yang memiliki nilai sejarah dan budaya yang sangat tinggi atau kegiatan budaya yang esensial. ${ }^{17}$

7. Kunjungan keluarga. Secara spesifik mengenai kesetaraan etnis, atau berkunjung pada tempat tinggal / kelahiran asli nenek moyang.

8. Status dan prestise, terkait dengan status/ gengsi karena hanya para wisatawan yang "mampu: melakukan perjalanan ke suatu tujuan pariwisata tertentu terutama yang membutuhkan biaya banyak. ${ }^{18}$

9. Profesional atau bisnis

Dari 9 motivasi tersebut maka negara yang ingin mengembangkan diri menjadi destinasi pariwisata halal kelas duniaberupaya agar pariwisata halal kelas "domestik" bisa lebih terkelolasecara optimal ketika mengidentifikasi potensi tempat wisata di kawasan untuk ditawarkan kepada calon wisatawan. ${ }^{19}$ Ini juga menyiratkan bahwa infrastruktur dan

${ }^{16}$ Kemenparekraf, \& Kemenparekraf. (n.d.). Peluang dan Tantangan Pengembangan Kepariwisataan di Indonesia. Kemenparekraf. Retrieved June 14, 2021, from https://www. kemenparekraf.id

${ }^{17}$ Sutono, A., Tahir, S., Sumaryadi, S., Hernowo, A., \& Rahtomo, W. (2021). The Implementation of Halal Tourism Ecosystem Model in Borobudur Temple as Tourism Area. Indonesian Journal of Halal Research, 3(1), 13-20. https://oi.org/10.15575/ijhar.v3i1.11119

${ }^{18}$ Yuliviona, R., Alias, Z., Abdullah, M., \& Azliyanti, E. (2019). The Relationship of Halal Tourism, Islamic Attributes, Experiential Value, Satisfaction And Muslim Revisit Intention In Framework. International Journal of Tourism $\mathcal{E}$ Hospitality Reviews, 6(1), 50-57. https://doi.org/10.18510/ijthr.2019.614

${ }^{19}$ Satriana, E. D., \& Faridah, H. D. (2018). Halal Tourism: Development, Chance And Challenge. Journal of Halal Product and Research, 1(2), 32. https://doi.org/10.20473/ jhpr.vol.1-issue. 2.32-43 
suprastruktur disediakan menjadi latar belakang pertimbangan seseorang untuk bepergian. Secara umum terdapat alasan positif mengapa destinasi pariwisata domestik perlu dikembangkan. ${ }^{20}$

Pertama, menjadi peluang suatu daerah menjadi destinasi pariwisata untuk menjadi "media" pemenuhan kebutuhan tersebut. Kedua, berbagai manfaat dan peluang ekonomi yang dapat diraih, antara lain; kesempatan kerja, meningkatkan kesejahteraan masyarakat sekitar destinasi pariwisata, meningkatkan nilai / citra suatu wilayah geografis, dan mendorong revitalisasi wilayah geografis yang sudah kehilangan daya tariknya, misalnya kota tua atau bekas kawasan pertambangan. Ketiga, bagi negara berkembang, industri pariwisata merupakan media pembangunan ekonomi yang tidak memerlukan banyak investasi dan memberikan keuntungan dalam jangka panjang. Daya tarik wisata merupakan inti dari pengembangan pariwisata. Keempat, Sektor pariwisata dapat mengurangi ketergantungan impor karena sebagian besar barang modal dan barang habis pakai disediakan oleh destinasi pariwisata, seperti kerajinan tangan, makanan dan minuman, serta tempat wisata. ${ }^{21}$ Kelima, untuk memperkuat nilai positif pariwisata. Estimasi awal pada tahun 2020 jumlah kunjungan internasional mencapai 1,56 miliar kali, dengan peningkatan jumlah perjalanan lalu lintas dari $18 \%$ menjadi $24 \%$, namun diperkirakan turun dengan cepat karena wabah covid-19.

${ }^{20} \mathrm{Ibid}$

${ }^{21}$ Halal Tourism Destination in UAE: The Opportunities, Threats and Future Research. (2019). International Journal of Innovative Technology and Exploring Engineering, 8(6S4), 788-793. https://doi.org/10.35940/ijitee.F1158.0486S419

Kodifikasia: Jurnal Penelitian Islam, Volume, 15 No. 1 Tahun 2021 


\section{Pariwisata Halal Global Versus Domestik}

\begin{tabular}{|c|c|c|c|c|c|c|c|}
\hline $\begin{array}{c}\text { Rank in } \\
2012\end{array}$ & Country & 1996 & 2000 & 2005 & 2010 & 2012 & Trend, 1995-2012 \\
\hline 1 & rrance & 50,0 & 77.2 & 75.0 & 77.6 & 810 & - \\
\hline 2 & United States & 43.5 & 51.2 & 49.2 & 5.8 .8 & 670 & \\
\hline 3 & China & 20.0 & 32.2 & 46.8 & s. 7 & 57.7 & \\
\hline 4 & Spain & 34.9 & 46.4 & 5.5 & $\$ 2.7$ & 57.7 & \\
\hline 5 & italy & 31.1 & 41.2 & 36.5 & 436 & 46.4 & \\
\hline 6 & Turkery & 7.1 & 2,6 & 20.1 & 32.4 & 35.7 & \\
\hline 7 & Germany & 14.8 & 19.0 & 22.5 & 26.9 & 30.4 & \\
\hline $\mathbf{s}$ & United Kingdom & $2 n .7$ & 23.2 & $2 * 0$ & 28.3 & 22.3 & \\
\hline 9 & Russian fecteration & 20.3 & 21.2 & 22.2 & 22.3 & 25.2 & \\
\hline 10 & Malaysia & 7.5 & 10.2 & 16.4 & 24.6 & 25.0 & - \\
\hline
\end{tabular}

Gambar 3. Negara yang paling ramai dikunjungi turis.

Sumber: Bank Dunia, 1995-2012

Dari gambar 3 diketahui bahwa Organisasi Pariwisata Dunia berupayadalam menyediakan data pariwisata global. Data juga terbatas karena wisatawan non-residen internasional di perbatasan negara tidak memiliki data. Data tersebut menunjukkan kedatangan pengunjung internasional pada hari yang sama termasuk didalamnya adalah penumpang kapal pesiar, dan kru transportasi. Untuk beberapa negara, data dikumpulkan dari statistik perbatasan (polisi, imigrasi dan mungkin dibatasi hanya untuk memasukkan udara atau kedatangan yang menginap di hotel..$^{22}$

Tidak mudah untuk berpindah dari pariwisata halal global beralih menjadi pariwisata domestik karena turis lebih memilih tujuan global daripada tujuan domestik, ${ }^{23}$ tetapi terkait dengan COVID-19, hal itu menjadi pilihan utama oleh kebijakan pemerintah setiap negara.

\section{Dampak Virus Corona terhadap Pariwisata Halal}

Alasan spiritual atau religious reason merupakan motivasi utama wisatawan untuk berpergian, hal ini menjadikan pembangunan pariwisata halal menjamin manfaat maksimal secara berkelanjutan melalui pendekatan kebijakan yang komprehensif dan terintegrasi. Indonesia yang dikenal sebagai destinasi pariwisata halal dapat mengembangkan pariwisata domestik secara terus menerus tanpa batas. Daya dukung terhadap jumlah wisatawan yang berkunjung ke suatu destinasi pariwisata atau objek wisata

${ }^{22}$ International tourism data: Top destinations, number of arrivals, and more. (n.d.). Retrieved June 14, 2021, from https://blogs.worldbank.org/opendata/internationaltourism-data-top-destinations-number-arrivals-and-more

${ }^{23}$ Surya, E. D., Ginting, P., Rini, E. S., \& Absah, Y. (n.d.). The Analysis Of Halal Tourism Products And Brand Image Destination On Tourists' Repeated Visits Via Trust In West Sumatera Province. 15. 
pada waktu tertentu merupakan hal essential untuk diwujudkan dalam pembangunan ekonomi pariwisata yang berkelanjutan.

Hal ini juga terkait dengan pemanfaatan sektor pariwisata dalam mendukung upaya pengentasan kemiskinan, sehingga pariwisata halal dilandasi semangat profesionalisme, yang merupakan hal penting dan harus terus ditingkatkan. Dengan demikian harapan pariwisata halal dapat meningkatkan kualitas layanan yang akhirnya dapat mendorong peningkatan pendapatan.

Pengembangan pariwisata halal dalam negeri juga harus berprinsip "happy here, happy there". Solusi untuk menyikapi wabah virus corona, terdapat dua solusi:

1. Pertama dengan meminta wisatawan untuk menunda dan tinggal di rumah demi kesehatan dan keselamatan mereka

2. Wisatawan kemudian dihimbau untuk mengalokasikan anggaran pariwisata mereka dari pariwisata ke dalam kegiatan sosial yang secara signifikan akan membantu masyarakat yang membutuhkan.

Berdasarkan poin dua di atas tentang landasan sosial, pariwisata halal akan berbangga hati jika ada tindak lanjut dari "calon wisatawan" untuk mengidentifikasi salah satu solusi bagi resesi ekonomi. Setiap negara memberikan status "hampir sama" dengan yang diberikan, hanya saja status ini tidak dinyatakan secara langsung (straight forward), tetapi dengan implikasi kebijakan, hal ini menunjukkan bahwa "fenomena covid-19" bersifat universal karena terjadi di hampir semua negara secara bersamaan, dengan demikian, dapat dikatakan bahwa seluruh umat manusia bersatu dalam upaya pencegahan Covid-19.

Karantina kebijakan untuk masing-masing negara adalah sesuatu yang alami. Lebih dari itu, hal tersebut merupakan garda depan sebuah negara yang bertujuan untuk mencegah penyebaran covid-19, oleh karenanya, solusi apa pun yang dimaksudkan untuk menyelesaikan wabah covid-19 dalam pariwisata halal secara global adalah dengan kembali ke pariwisata halal domestik negara masing-masing. Setiap negara memberikan solusi yang paling rasional dan manusiawi, konsep "back to domestic nature", dimana setiap wisatawan menikmati kebijakan pariwisata oleh pemerintah secara "otonomi" dengan mengikuti negaranya masing-masing. Dengan demikian, pariwisata halal dalam negeri telah memberikan solusi yang "maksimal" terhadap permasalahan yang saat ini tercatat dalam sejarah.

\section{PENUTUP}

Virus corona memberikan dampak yang sangat signifikan terhadap perkembangan pariwisata halal di berbagai belahan dunia. Kebijakan 
pemerintah yang fokus pada penanganan kesehatan dan penyebaran virus corona dengan membatasi mobilitas wisatawan menjadikan prosesntase kunjungan wisatawan ke tempat wisata juga menurun. Virus corona secara signifikan memengaruhi masa depan pariwisata halal di destinasi global, sehingga destinasi domestik adalah solusi dari dampak virus corona untuk mencegah kerugian yang lebih besar pada pariwisata halal. Virus coronavirus menyatukan aktor-aktor utama yang terkait dengan pariwisata halal: medis, kebijakan global dan domestik, akademisi, fasilitas, layanan elektronik, akomodasi dan penerbangan. 


\section{DAFTAR RUJUKAN}

Anderson, R. M., Heesterbeek, H., Klinkenberg, D., \& Hollingsworth, T. D. (2020). How will country-based mitigation measures influence the course of the COVID-19 epidemic? Lancet (London, England), 395 (10228), 931-934. https://doi.org/10.1016/S0140-6736(20)305675

Azam, S. E., Abdullah, M. A., \& Razak, D. A. (2019). Halal Tourism: Definition, Justification, And Scopes Towards Sustainable Development. 18(3), 9.

Battour, M., Hakimian, F., Ismail, M. N., \& Boğan, E. (2018). The Perception of Non-Muslim Tourists towards Halal Tourism: Evidence from Turkey and Malaysia. Journal of Islamic Marketing, 9(4), 823-840. https://doi. org/10.1108/JIMA-07-2017-0072

Coronavirus Death Toll and Trends-Worldometer. (n.d.). Retrieved June 14,2021, from https://www.worldometers.info/coronavirus/coronavirusdeath-toll/?fbclid=IwAR3ct-OjVs6SY1ZqHGMP53akUSGsP8Nkvp7xJ32BrqA0sMXo3IvBzu6I3E

Destiana, R., \& Kismartini, K. (2020). Halal Tourism Marketing in the Disruption Era: A Case Study of Penyengat Island in Riau Islands Province. Society, 8(1), 264-283. https://doi.org/10.33019/society. v8i1.174

Djakfar, D. H. M. (n.d.). Peta Jalan Menuju Pengembangan Akademik \& Industri Halal di Indonesia. 238.

Faheem Younus: During coronavirus pandemic, leave denial, leave panic. Live in preparedness [Commentary]-Baltimore Sun. (n.d.). Retrieved June 14, 2021, from https://www.baltimoresun.com/maryland/harford/ aegis/opinion/cng-ag-commentary-coronavirus-younus-202003185xymml75ajal3fotzsibvqhfjq-story.html

Fitrianto, F. (2019). Pengembangan Ekonomi Indonesia Berbasis Wisata Halal. BISNIS : Jurnal Bisnis dan Manajemen Islam, 7(1), 69. https:// doi.org/10.21043/bisnis.v7i1.5254

Global Muslim Travel Index 2018. (n.d.). Retrieved June 14, 2021, from https://www.crescentrating.com/reports/mastercard-crescentratingglobal-muslim-travel-index-gmti-2018.html 
Halal Tourism Destination in UAE: The Opportunities, Threats and Future Research. (2019). International Journal of Innovative Technology and Exploring Engineering, 8(6S4), 788-793. https://doi.org/10.35940/ ijitee.F1158.0486S419

International tourism data: Top destinations, number of arrivals, and more. (n.d.). Retrieved June 14, 2021, from https://blogs.worldbank. org/opendata/international-tourism-data-top-destinations-numberarrivals-and-more

Jaelani, A. (2017). Halal Tourism Industry in Indonesia: Potential and Prospects. SSRN Electronic Journal. https://doi.org/10.2139/ ssrn.2899864

Kemenparekraf, \& Kemenparekraf. (n.d.). Peluang dan Tantangan Pengembangan Kepariwisataan di Indonesia. Kemenparekraf. Retrieved June 14, 2021, from https://www.kemenparekraf.id

Kodirov, D., Mavlonova, U., Kodirov, T., \& Allayarova, N. (2020). Halal Tourism in Central Asia: Developing Service Systems in Uzbekistan. $1(2), 11$.

Koonin, L. M. (2020). Novel coronavirus disease (COVID-19) outbreak: Now is the time to refresh pandemic plans. Journal of Business Continuity \& Emergency Planning, 13(4), 1-15.

Peristiwo, H. (2020). Indonesian and Malaysian potential for a Halal Tourism Industry. Tourism and Leisure, 9, 16.

Pesona, S. (n.d.). Pedoman Pariwisata Halal Jawa Barat. 56.

Satriana, E. D., \& Faridah, H. D. (2018). Halal Tourism: Development, Chance And Challenge. Journal of Halal Product and Research, 1(2), 32. https://doi.org/10.20473/jhpr.vol.1-issue.2.32-43

Surya, E. D., Ginting, P., Rini, E. S., \& Absah, Y. (n.d.). The Analysis Of Halal Tourism Products And Brand Image Destination On Tourists' Repeated Visits Via Trust In West Sumatera Province. 15.

Sutono, A., Tahir, S., Sumaryadi, S., Hernowo, A., \& Rahtomo, W. (2021). The Implementation of Halal Tourism Ecosystem Model in Borobudur Temple as Tourism Area. Indonesian Journal of Halal Research, 3(1), 13-20. https://doi.org/10.15575/ijhar.v3i1.11119

Syahid,P.D.W.H.D.-V.G. 2016. (2015, July 22).Pariwisata Halal: Pengertian, Prinsip dan Prospeknya. Studi Pariwisata. https://studipariwisata.com/ referensi/pariwisata-halal/ 


\section{4 | Shinta Maharani, Asmak Ab Rahman}

The Global Macroeconomic Impacts of COVID-19: Seven Scenarios by Warwick J. McKibbin, Roshen Fernando: SSRN. (n.d.). Retrieved June 14, 2021, from https://papers.ssrn.com/sol3/papers.cfm?abstract_ $\mathrm{id}=3547729$

Yuliviona, R., Alias, Z., Abdullah, M., \& Azliyanti, E. (2019). The Relationship of Halal Tourism, Islamic Attributes, Experiential Value, Satisfaction And Muslim Revisit Intention In Framework. International Journal of Tourism \& Hospitality Reviews, 6(1), 50-57. https://doi. org/10.18510/ijthr.2019.614 